\title{
Tryptophan, threonine and isoleucine supplementation in low- protein diets for commercial laying hens
}

\section{Suplementação de triptofano, treonina e isoleucina em dietas com baixo nível protéico para poedeiras comerciais}

\author{
Iván Camilo Ospina Rojas ${ }^{1}$; Alice Eiko Murakami²; Jamile Corina Fanhani ${ }^{1}$; \\ Karla Paola Picoli ${ }^{1}$; Maria José Baptista Barbosa ${ }^{3}$
}

\begin{abstract}
Isoleucine (Ile), threonine (Thr) and tryptophan (Trp) are most likely candidates for becoming third limiting amino acids (AA) in layer diets. This work studied the effect of supplementing Ile, Thr and Trp in low-protein diets on the productive performance, egg quality and serum parameters of Hy-Line W36 laying hens. A total of 36030 -week-old laying hens were distributed in a completely randomized design into 9 treatments with 5 replications of 8 birds each. Treatments consisted of a control diet that was based on corn and soybean meal formulated with $15.5 \% \mathrm{CP}$. A second diet with $13 \% \mathrm{CP}$ was formulated to meet the requirements for all essential AA of the control diet, except for Ile, Thr and Trp. The other treatments consisted of individual and combined supplementation of the aforementioned AA in the $13 \%$ $\mathrm{CP}$ diet. The reduction of the dietary protein level negatively influenced $(\mathrm{p}<0.05)$ the productivity of the hens, impairing egg production, feed conversion $\left(\mathrm{kg} \mathrm{kg}^{-1}\right.$ and $\mathrm{kg} \mathrm{dz}^{-1}$ ), and egg mass. However, these variables were restored with individual and combined supplementation of the three AA in the $13 \% \mathrm{CP}$ diet. Individually-supplemented diets with Ile, or combined with Thr and/or Trp, resulted in hens with lower $(\mathrm{p}<0.05)$ serum uric acid and ammonia concentrations as compared to birds receiving diets with $15.5 \%$ (control) and $13 \% \mathrm{CP}$. The protein levels can be reduced $(13 \% \mathrm{CP})$ in the diet of commercial laying hens without compromising performance, egg quality or serum parameters with individual Ile, Thr or Trp supplementation.
\end{abstract}

Key words: Amino acid, crude protein, egg quality, performance, poultry

\section{Resumo}

A isoleucina (Ile), treonina (Thr) e triptofano (Trp) são os possíveis candidatos a ser o terceiro aminoácido (AA) limitante na dieta de poedeiras comerciais. Este estudo foi realizado com objetivo de avaliar o efeito da suplementação da Ile, Thr e Trp sobre o desempenho produtivo, qualidade de ovos e parâmetros séricos de poedeiras Hy-Line W36 alimentadas com dietas contendo baixo nível de PB. Um total de 360 poedeiras com 30 semanas de idade foram distribuídas em um delineamento inteiramente casualizado com 9 tratamentos e 5 repetições com 8 aves por unidade experimental. Os tratamentos foram constituídos por uma dieta controle a base de milho e farelo de soja formulada com $15,5 \%$ de PB. Uma segunda dieta com $13 \%$ PB foi formulada para encontrar exigências de todos os AA essências da dieta controle, exceto para a Ile, Thr e Trp. Os demais tratamentos foram constituídos pela suplementação isolada ou combinada dos três AA na dieta com $13 \%$ de PB. A redução do nível protéico da dieta influenciou negativamente $(\mathrm{p}<0,05)$ a produtividade das aves, piorando a produção de ovos,

1 Discentes do Programa de Pós-Graduação em Zootecnia, Universidade Estadual de Maringá, UEM, Maringá, PR, Brasil. E-mail: icospinarojas@gmail.com; jamilefanhanii@hotmail.com; kppicoli@hotmail.com

2 Prof ${ }^{a}$, Dept $^{0}$ de Zootecnia, UEM, Maringá, PR, Brasil. E-mail: aemurakami@uem.br

3 Prof $^{\mathrm{a}}$, Dept ${ }^{\mathrm{o}}$ de Medicina Veterinária, UEM, Campus Umuarama, Maringá, PR, Brasil. E-mail: mjbbarbosa@uem.br

Author for correspondence 
conversão alimentar $\left(\mathrm{kg} \mathrm{kg}^{-1} \mathrm{e} \mathrm{kg} \mathrm{dz}^{-1}\right)$ e massa de ovos. No entanto, estas variáveis foram restabelecidas na mesma proporção à dieta controle com a suplementação isolada ou combinada dos três AA estudados na dieta com 13\% de PB. Dietas suplementadas individualmente com Ile ou em combinação com Thr e/ou Trp resultaram em aves com menores $(\mathrm{p}<0,05)$ concentrações séricas de ácido úrico e amônia que as aves que receberam as dietas com 15,5 (controle) e 13\% de PB. Os resultados indicam que a proteína pode ser reduzida $(13 \% \mathrm{~PB})$ na dieta de poedeiras comerciais sem comprometer o desempenho, qualidade do ovo nem os parâmetros séricos com a suplementação individual de Ile, Thr ou Trp.

Palavras-chave: Aminoácido, avicultura, desempenho, proteína bruta, qualidade de ovo

\section{Introduction}

Nutritionists are interested in using lower protein levels in feeds for commercial laying hens, as compared to the feeds normally used in the industry, due to the high cost of protein ingredients and increasing pressure to reduce nitrogen excretion into the environment.

Research on bird and swine species have shown that supplementation with industrial amino acids (AA) on low-CP diets is an effective method to reduce feed costs and minimize nitrogen excretion (CANH et al., 1998; OSPINA-ROJAS et al., 2012).

However, progressive diet $\mathrm{CP}$ reduction can lead to a deficiency in AA known as "less limiting", and which are usually provided by diets containing normal CP levels (PEGANOVA; EDER, 2002). This is the case with AA threonine (Thr), tryptophan (Trp) and isoleucine (Ile), making them possible candidates to become the third limiting AA in commercial layers fed low-protein diets (LOCATELLI, 2005).

In practice, limiting AA deficiency is prevented with industrial supplementation. Keshavarz and Jackson (1992) reported increased egg weight as a result of supplementation with lysine (Lys) and methionine (Met) in low-CP diets (15\%); however, egg weight was not the same as that obtained with the control diet (18\% CP). Likewise, Harms and Ivey (1993) affirmed that Met and Lys supplementation did not restore reduced egg mass in laying hens receiving low-CP diets $(14.5 \% \mathrm{CP})$. These studies reveal that, in addition to Lys and Met, other essential AA can compromise the performance of birds fed these diets.
In that regard, Sohail et al. (2002) found that layer diets based on Lys are deficient in Ile, Thr and Trp. According to Morris and Gous (1988), Ile could be the third limiting AA in laying hen diets when considering egg production. However, Russell and Harms (1999), and later Locatelli (2005), affirmed that Trp is the third limiting AA in corn-soybean meal diets based on data from the literature. For their part, Harms and Ivey (1993) affirmed that in addition to Trp, Thr could be the likely limiting AA after Met and Lys for commercial laying hens by considering egg production and egg mass.

Therefore, there certainly is controversy among the different studies on the limitation order of "less limiting" AA in commercial layer diets. This order depends mainly on the ingredients used to formulate the diets, as well as the strain and the bird's age (CORZO, 2007). Based on these data, the objective of this work was to evaluate the effect of supplementation with AA Ile, Thr and Trp on the productive performance, egg quality and serum parameters of Hy-Line W36 laying hens fed diets containing low CP levels.

\section{Material and Methods}

The experiment was conducted in the Aviculture sector of the Iguatemi Experimental Farm of the Universidade Estadual de Maringá (UEM) in Brazil. A total of 36030 week-old Hy-Line W36 commercial laying hens were distributed in a completely randomized design into 9 treatments with 5 replications of 8 birds each using a completely randomized design. The experimental period lasted 84 days, divided into 3 cycles of 28 days each. 
The light schedule was increased from the start of the laying period, peaking at 17 hours. The light schedule was created using incandescent lamps controlled by a timer. The egg laying control was carried out between 28 and 30 weeks of age in order to standardize the laying rate. Next, the laying hens were allotted according to body weight and laying rate, prior to receiving the experimental diets.

The experimental diets were formulated to meet the nutritional requirements of the specific lineage (HY-LINE W-36, 2009-2011) during laying, and then they were balanced according to the chemical composition and energy values of the feeds, as described by Rostagno et al. (2011).

The treatments consisted of a control diet based on corn and soybean meal, formulated with 15.5\% CP. A second diet with $13 \% \mathrm{CP}$ was formulated to meet the requirements for all essential $\mathrm{AA}$ of the control diet, except Ile, Thr and Trp. The other treatments consisted of individual and combined supplementation of the aforementioned AA in the 13\% CP diet (Table 1), as follows: Trp; Thr; Ile; Trp +Ile; Trp + Thr; Thr +Ile and Trp +Ile +Thr.

To evaluate the performance and egg quality, the following were analyzed: feed intake $\left(\mathrm{g} \mathrm{day}^{-1}\right)$, egg production (\%), feed conversion $\left(\mathrm{kg} \mathrm{kg}^{-1}\right.$ and $\mathrm{kg} \mathrm{dz}^{-}$ $\left.{ }^{1}\right)$, egg mass $\left(\mathrm{g}\right.$ day $\left.{ }^{-1}\right)$, egg weight (g), Haugh unit, specific gravity $\left(\mathrm{g} \mathrm{L}^{-1}\right)$, shell percentage $(\%)$ and shell thickness $(\mathrm{mm})$.

Feed intake was controlled in each 28-day cycle. Eggs were collected daily and marked according to cage to determine the total egg production and laying percentage. On the last four days of each cycle, all eggs were weighed individually using a precision digital scale $(0.001 \mathrm{~g})$ in order to obtain the mean egg weight. The egg mass was calculated by multiplying egg production by egg weight, and the feed conversion was determined by dividing feed intake by production in egg dozens $\left(\mathrm{kg} \mathrm{dz}^{-1}\right)$ and egg mass in kilograms $\left(\mathrm{kg} \mathrm{kg}^{-1}\right)$ at each of the three cycles.

The internal egg quality was evaluated by the specific gravity and Haugh unit. To analyze specific gravity, the eggs were immersed in different saline solutions, adjusted using an oil densimeter, at densities of 1.070, 1.074, 1.078, 1.082 and $1.086 \mathrm{~g}$ $\mathrm{mL}^{-1}$. The Haugh unit (HU) was obtained using the formula proposed by Haugh (1937). HU = $100 \times \log$ $\left(\mathrm{h}+7.57-1.7 \mathrm{p}^{0.37}\right)$, in which $\mathrm{h}$ refers to albumen height $(\mathrm{mm})$ and $\mathrm{p}$ represents egg weight $(\mathrm{g})$. Albumen height was obtained at $5 \mathrm{~mm}$ from the yolk using a micrometer (Mitutoyo Corp., Kawasaki, Kanagawa, Japan) with $0.1 \mathrm{~mm}$ precision.

For external egg quality, the percentage and thickness $(\mathrm{mm})$ of the eggshells were determined by collecting samples of three eggs per replicate cage. The shells were rinsed and dried at room temperature for 48 hours. They were then weighed, and the shell percentage was calculated in relation to the egg's weight. Next, the thickness of these shells was calculated using a micrometer with 0.1 $\mathrm{mm}$ precision.

At the end of the experimental period, blood samples $\left(2 \mathrm{ml} \mathrm{bird}^{-1}\right)$ were collected from the jugular vein of 2 birds per replicate cage. The samples were kept on ice and centrifuged at $3000 \mathrm{x}$ g for $10 \mathrm{~min}$ at $4^{\circ} \mathrm{C}$. The resulting serum was collected and stored at $-70^{\circ} \mathrm{C}$ until analysis. The serum samples were thawed to $4^{\circ} \mathrm{C}$, and the serum uric acid and albumin concentrations were determined using commercial kits (Gold Analisa Ltda, Belo Horizonte, Brazil). Serum ammonia was determined as described by Ishihard et al. (1972) using a procedure where ammonia reacts with 2-ketoglutarate and NADH in a reaction catalyzed by the glutamate+dehydrogenase enzyme, resulting in the oxidation of $\mathrm{NADH}$ to NAD. NADH consumption, measured by absorbance, is proportional to the concentration of ammonia in the sample. 
Table 1. Ingredients and nutrient composition of the experimental diets.

\begin{tabular}{|c|c|c|}
\hline Treatment & Control $(15.5 \% \mathrm{CP})$ & Low CP $(13.0 \% \mathrm{CP})$ \\
\hline Corn & 64.0 & 69.3 \\
\hline Soybean meal $45 \%$ & 17.9 & 14.5 \\
\hline Dicalcium Phosphate & 2.1 & 2.2 \\
\hline Soybean Oil & 2.4 & 2.2 \\
\hline Limestone & 9.4 & 9.4 \\
\hline $\mathrm{NaCl}$ & 0.4 & 0.4 \\
\hline Suppl., Vit-Min ${ }^{1}$ & 0.25 & 0.25 \\
\hline BHT (Butylated hydroxytoluene) & 0.01 & 0.01 \\
\hline Inert $^{2}$ & - & 1.00 \\
\hline DL-Met 99\% & 0.23 & 0.25 \\
\hline L-Lys HCL 78.5\% & 0.21 & 0.30 \\
\hline L-Arg 99\% & - & 0.09 \\
\hline L-Val 98\% & 0.11 & 0.16 \\
\hline L-Glu 99.4\% & 2.78 & - \\
\hline L-Trp 98\% & 0.02 & - \\
\hline L-Thr $98 \%$ & 0.07 & - \\
\hline L-Ile $98 \%$ & 0.09 & - \\
\hline \multicolumn{3}{|l|}{ Calculated values } \\
\hline $\mathrm{CP}, \%$ & 15.5 & 13.0 \\
\hline ME, kcal kg-1 & 2894 & 2894 \\
\hline Calcium, \% & 4.20 & 4.20 \\
\hline Available Phosphorus, \% & 0.28 & 0.28 \\
\hline Chlorine, \% & 0.48 & 0.48 \\
\hline Potassium, \% & 0.51 & 0.46 \\
\hline Sodium, \% & 0.18 & 0.18 \\
\hline Digestible Val,\% & 0.68 & 0.68 \\
\hline Digestible Lys, $\%$ & 0.75 & 0.75 \\
\hline Digestible Met + Cys, $\%$ & 0.63 & 0.63 \\
\hline Digestible Leu, \% & 1.19 & 1.12 \\
\hline Digestible Trp, \% & 0.16 & 0.12 \\
\hline Digestible Thr, \% & 0.53 & 0.42 \\
\hline Digestible Ile, $\%$ & 0.59 & 0.46 \\
\hline
\end{tabular}

${ }^{1}$ Composition per kg of diet: Vit. A - 12,000 IU, Vit. D3 - 2,500 IU, DL- $\alpha$-tocopherol acetate $-20 \mathrm{mg}$, Thiamine $-3 \mathrm{mg}$, Riboflavin $-5 \mathrm{mg}$, Pyridoxine $-3 \mathrm{mg}$, Vit. B12 - $20 \mu \mathrm{g}$, Vit. $\mathrm{K}_{3}-1.2 \mathrm{mg}$, Calcium Pantothenate $-1.5 \mathrm{~g}$, Niacin $-30 \mathrm{mg}$, Folic Acid -0.5 $\mathrm{mg}$, Biotin $-0.1 \mathrm{mg}$, Choline chloride $-150 \mathrm{mg}$, Zinc $-60 \mathrm{mg}$, Iron - $25 \mathrm{mg}$, Copper - $5 \mathrm{mg}$, Cobalt $-0.1 \mathrm{mg}$, Selenium $-0.2 \mathrm{mg}$. ${ }^{2}$ Inert (kaolin) - The addition of industrial AA replaced the inert ingredient.

The data were analyzed by ANOVA, followed by a Tukey's test, using a randomized complete design. All data were analyzed using the GLM procedure of SAS software (SAS, 2009). Statistical significance was considered to be $\mathrm{P} \leq 0.05$.

\section{Results and Discussion}

The reduction in dietary protein levels negatively influenced $(p<0.05)$ the productivity of the hens, impairing egg production, feed conversion ( $\mathrm{kg}$ $\mathrm{kg}^{-1}$ and $\mathrm{kg} \mathrm{dz}^{-1}$ ) and egg mass, even though these diets were supplemented with several essential AA (Table 2). It is possible that deficiencies of other AA besides those supplemented in the diet affected the performance of these birds. This affirmation is valid because the individual and combined supplementation of Ile, Trp and Thr in the 13\% CP diet restored performance to the same level as the control diet. 
Table 2. Performance of Hy-Line W36 laying hens fed low-crude-protein diets supplemented with tryptophan, threonine and isoleucine.

\begin{tabular}{lcccc}
\hline Treatments & $\begin{array}{c}\text { Feed intake } \\
(\mathrm{g} \mathrm{day})\end{array}$ & $\begin{array}{c}\text { Egg production } \\
(\%)\end{array}$ & $\begin{array}{c}\text { FCR } \\
\left(\mathrm{kg} \mathrm{kg}^{-1}\right)\end{array}$ & $\begin{array}{c}\text { FCR } \\
\left(\mathrm{Kg} \mathrm{dz}^{-1}\right)\end{array}$ \\
\hline Control $(15.5 \% \mathrm{CP})$ & $101.36^{\mathrm{ab}}$ & $85.98^{\mathrm{ab}}$ & $1.993^{\mathrm{ab}}$ & $1.418^{\mathrm{abc}}$ \\
Reduced CP $(13 \% \mathrm{CP})$ & $102.45^{\mathrm{a}}$ & $79.63^{\mathrm{c}}$ & $2.199^{\mathrm{c}}$ & $1.548^{\mathrm{d}}$ \\
$13 \% \mathrm{CP}+$ Trp & $102.35^{\mathrm{a}}$ & $82.91^{\mathrm{bc}}$ & $2.068^{\mathrm{b}}$ & $1.483^{\mathrm{cd}}$ \\
$13 \% \mathrm{CP}+$ Thr & $99.04^{\mathrm{b}}$ & $82.61^{\mathrm{bc}}$ & $2.045^{\mathrm{ab}}$ & $1.441^{\mathrm{abc}}$ \\
$13 \% \mathrm{CP}+\mathrm{Ile}$ & $101.47^{\mathrm{ab}}$ & $85.40^{\mathrm{ab}}$ & $2.004^{\mathrm{ab}}$ & $1.428^{\mathrm{abc}}$ \\
$13 \% \mathrm{CP}+$ Trp $+\mathrm{Ile}$ & $102.97^{\mathrm{ab}}$ & $86.51^{\mathrm{a}}$ & $2.004^{\mathrm{ab}}$ & $1.430^{\mathrm{abc}}$ \\
$13 \% \mathrm{CP}+$ Trp + Thr & $101.96^{\mathrm{ab}}$ & $86.96^{\mathrm{a}}$ & $2.020^{\mathrm{ab}}$ & $1.410^{\mathrm{ab}}$ \\
$13 \% \mathrm{CP}+\mathrm{Thr}+\mathrm{Ile}$ & $102.94^{\mathrm{ab}}$ & $84.88^{\mathrm{ab}}$ & $2.035^{\mathrm{ab}}$ & $1.458^{\mathrm{bc}}$ \\
$13 \% \mathrm{CP}+\operatorname{Trp}+\mathrm{Ile}+\mathrm{Thr}$ & $101.58^{\mathrm{ab}}$ & $87.67^{\mathrm{ab}}$ & $1.942^{\mathrm{a}}$ & $1.392^{\mathrm{a}}$ \\
SEM & 1.57 & 1.72 & 0.05 & 0.03 \\
\hline
\end{tabular}

abdmeans followed by different letters in the same column differ significantly using a Tukey's test $(\mathrm{P}<0.05)$.

Likewise, Sohail et al. (2002) affirmed that laying hen diets formulated with Lys are deficient in Ile, Thr and Trp, as these authors found positive responses on layer performance with diets supplemented with these AA. The imbalance between the AA in the diet is likely the reason that low-CP diets do not always result in laying hens that have a similar productive performance to the hens that receive diets with adequate CP (KESHAVARZ; JACKSON, 1992).

Diets supplemented individually with Trp or Thr resulted in birds with lower $(\mathrm{p}<0.05)$ production and egg mass than those that received the diet supplemented with all three AA (Thr, Trp and Ile) (Tables 2 and 3). Conversely, in all treatments where Ile was supplemented, hens showed similar performance and egg quality as layers that received diet supplementation with all three of the studied AA, indicating that Ile is a potentially limiting AA in low-CP diets for laying hens. This confirms the results found by other authors (SHIVAZAD et al., 2002; PEGANOVA; EDER, 2003; RECH et al., 2010).
Diets supplemented only with Ile or Thr resulted in laying hens with equal feed conversion $(\mathrm{kg}$ $\mathrm{kg}^{-1}$ and $\mathrm{kg} \mathrm{dz}^{-1}$ ), similar to birds fed with the diet supplemented with all three of the evaluated AA, whereas hens that received only Trp supplementation did not achieve the same results.

Penz and Jensen (1991), despite providing experimental diets with sufficient levels to meet $120 \%$ of Met, Lys and Trp requirements for hens, found that low-protein diets $(13 \% \mathrm{CP})$ resulted in laying hens with higher feed conversion than the birds that received the control diet $(13 \% \mathrm{CP})$.

The low levels of Ile in corn and soybean meal predispose Ile to becoming a limiting AA for bird growth in vegetable-based diets with lower protein levels (FERNANDEZ et al., 1994; KIDD et al., 2004). Therefore, Ile industrial supplementation is essential in these diets (MELLO et al., 2012). However, this supplementation must be performed with caution, as there is a narrow margin between the requirements and excess amounts of this AA for laying hens (PEGANOVA; EDER, 2002). 
Table 3. Egg quality for Hy-Line W36 laying hens fed low-crude protein diets supplemented with tryptophan, threonine and isoleucine'.

\begin{tabular}{|c|c|c|c|c|c|c|}
\hline Treatments & $\begin{array}{l}\text { EW } \\
(g)\end{array}$ & $\begin{array}{c}\text { EM } \\
(\mathrm{g})\end{array}$ & $\mathrm{HU}$ & $\begin{array}{c}\mathrm{SG} \\
\left(\mathrm{g} \mathrm{L}^{-1}\right)\end{array}$ & $\begin{array}{l}\text { Eggshell } \\
(\%)\end{array}$ & $\begin{array}{l}\text { Eggshell thickness } \\
(\mathrm{mm})\end{array}$ \\
\hline Control $(15 \%$ CP) & 59.27 & $50.96^{\mathrm{abc}}$ & 94.12 & 1.138 & 9.02 & 0.48 \\
\hline Reduced CP (13\% CP) & 58.69 & $46.71^{\mathrm{d}}$ & 95.10 & 1.141 & 9.17 & 0.49 \\
\hline $13 \% \mathrm{CP}+\operatorname{Trp}$ & 59.79 & $49.59^{\mathrm{bc}}$ & 94.76 & 1.138 & 9.11 & 0.49 \\
\hline $13 \% \mathrm{CP}+\mathrm{Thr}$ & 58.76 & $48.55^{\mathrm{cd}}$ & 95.13 & 1.140 & 9.00 & 0.48 \\
\hline $13 \% \mathrm{CP}+\mathrm{Ile}$ & 59.41 & $50.73^{\mathrm{abc}}$ & 94.45 & 1.130 & 9.21 & 0.49 \\
\hline $13 \% \mathrm{CP}+\mathrm{Trp}+\mathrm{Ile}$ & 59.48 & $51.46^{\mathrm{ab}}$ & 94.82 & 1.133 & 9.01 & 0.48 \\
\hline $13 \% \mathrm{CP}+\mathrm{Trp}+\mathrm{Thr}$ & 58.16 & $50.58^{\mathrm{abc}}$ & 95.11 & 1.129 & 9.03 & 0.48 \\
\hline $13 \% \mathrm{CP}+\mathrm{Thr}+\mathrm{Ile}$ & 59.71 & $50.67^{\mathrm{abc}}$ & 94.64 & 1.138 & 8.97 & 0.48 \\
\hline $13 \% \mathrm{CP}+\mathrm{Trp}+\mathrm{Ile}+\mathrm{Thr}$ & 59.76 & $52.39^{\mathrm{a}}$ & 94.89 & 1.133 & 9.00 & 0.48 \\
\hline SEM & 1.02 & 1.23 & 1.03 & 0.01 & 0.17 & 0.01 \\
\hline
\end{tabular}

${ }^{1} \mathrm{EW}=$ egg weight, $\mathrm{EM}=$ egg mass, $\mathrm{HU}=$ haugh unit, $\mathrm{SG}=$ specific gravity.

abcdmeans followed by different letters in the same column differ significantly using a Tukey's test $(\mathrm{P}<0.05)$.

Ile levels above the required levels compromise bird performance (PEGANOVA; EDER, 2003), as a result of the antagonist effect between Ile and the other two branched-chain AA (Val and Leu). This is because these AA share the same transportation systems through the cell membrane and are degraded by the same enzyme - dehydrogenase of branchedchain $\alpha$-keto acids (HARRIS et al., 2001).

Harms and Ivey (1993), and more recently Mello et al. (2012), did not find any improvement in the productive parameters for laying hens supplemented with Ile. The imbalance among branched-chain AA may have been the reason those authors did not find positive responses on bird performance.

Low-CP diets can present imbalances among branched-chain AA, in which one or more of these AA may be at marginal levels. This includes high diet levels of Leu from corn protein (WALDROUP et al., 2002), as corn protein is disproportionately high in Leu compared to Val and Ile, with values of $1.01 \%$, $0.40 \%$ and $0.29 \%$, respectively (ROSTAGNO et al., 2011).
High Leu content in the diet increases the Val and Ile requirements, especially when the latter two AA are limited in the diet (D'MELLO; LEWIS, 1970). As such, in the present study, the experimental reduced-protein diets were supplemented with Val to meet bird requirements and avoid an imbalance among branched-chain AA.

Egg weight, Haugh unit, specific gravity, eggshell percentage and thickness were not affected by the treatments $(p>0.05)$. Layers that received the diet with $13 \% \mathrm{CP}$ without AA supplementation presented higher $(p<0.05)$ serum ammonia concentrations than did the birds fed with the other treatments (Table 4), indicating an AA imbalance in this diet.

Diets with reduced CP that are deficient in one or more AA leads to the deamination of other dietetic AA that are now in excess. The resulting nitrogen (ammonia) is excreted as uric acid. Ammonia is inevitably released in the catabolism of the proteins, but is extremely toxic to animal tissues. High serum levels of ammonia in the hens that received the diet with 13\% CP may be the reason for the lower performance observed in those birds. 
Table 4. Serum parameters for Hy-Line W36 laying hens fed low-crude-protein diets protein supplemented with tryptophan, threonine and isoleucine.

\begin{tabular}{lccc}
\hline Treatments & $\begin{array}{c}\text { Uric acid } \\
\left(\mathrm{mg} \mathrm{dL}^{-1}\right)\end{array}$ & $\begin{array}{c}\text { Ammonia } \\
\left(\mathrm{mmol} \mathrm{L}^{-1}\right)\end{array}$ & $\begin{array}{c}\text { Albumin } \\
\left(\mathrm{mg} \mathrm{dL}^{-1}\right)\end{array}$ \\
\hline Control $(15 \% \mathrm{CP})$ & $6.18^{\mathrm{a}}$ & $6.37^{\mathrm{b}}$ & 2.09 \\
Reduced CP $(13 \% \mathrm{CP})$ & $6.28^{\mathrm{a}}$ & $7.07^{\mathrm{a}}$ & 2.32 \\
$13 \% \mathrm{CP}+\operatorname{Trp}$ & $4.80^{\mathrm{ab}}$ & $6.09^{\mathrm{b}}$ & 2.04 \\
$13 \% \mathrm{CP}+\mathrm{Thr}$ & $4.52^{\mathrm{ab}}$ & $5.97^{\mathrm{bc}}$ & 2.23 \\
$13 \% \mathrm{CP}+\mathrm{Ile}$ & $3.69^{\mathrm{b}}$ & $5.62^{\mathrm{c}}$ & 2.27 \\
$13 \% \mathrm{CP}+\operatorname{Trp}+\mathrm{Ile}$ & $3.88^{\mathrm{b}}$ & $5.87^{\mathrm{c}}$ & 2.21 \\
$13 \% \mathrm{CP}+\operatorname{Trp}+\mathrm{Thr}$ & $4.88^{\mathrm{ab}}$ & $5.94^{\mathrm{bc}}$ & 2.04 \\
$13 \% \mathrm{CP}+$ Thr $+\mathrm{Ile}$ & $3.21^{\mathrm{b}}$ & $5.77^{\mathrm{c}}$ & 2.20 \\
$13 \% \mathrm{CP}+\operatorname{Trp}+\mathrm{Ile}+\mathrm{Thr}$ & $3.37^{\mathrm{b}}$ & $5.59^{\mathrm{c}}$ & 2.32 \\
SEM & 1.10 & 0.22 & 0.27 \\
\hline
\end{tabular}

${ }^{a b c}$ means followed by different letters in the same column differ significantly using a Tukey's test $(\mathrm{P}<0.05)$.

Diets supplemented individually with Ile or in combination with Thr and/or Trp resulted in hens with lower $(\mathrm{p}<0.05)$ serum uric acid and ammonia concentrations as compared to the birds that received diets with $15.5 \%$ (control) and 13\% CP. The control diet was supplemented with several AA. It is known that the rate of absorption of the industrial AA is higher than AA from an intact protein (NAMROUD et al., 2008). Thus, the rapid flux of ingested free AA into the blood stream may cause an imbalanced plasma AA profile (AFTAB et al., 2006), which could explain, in part, that the control diet resulted in laying hens that had high serum levels of uric acid, similar to those found in birds that received the $13 \% \mathrm{CP}$ diet.

In the present study, the results obtained in the production and egg mass variables, as well as those found in serum parameters, suggest that Ile can be the third limiting AA for laying hens fed under these diet conditions. Thr could precede Ile in the order of limitation, based on the results obtained for feed conversion $\left(\mathrm{kg} \mathrm{kg}^{-1}\right.$ and $\left.\mathrm{kg} \mathrm{dz}^{-1}\right)$. However, further studies should be performed to standardize the next limiting AA after Met and Lys in laying hens; this criterion has already been established in the formulation of practical diets for broilers.
Knowledge of the limiting order of AA and the standardization of its requirements make it possible to use lower protein levels in diets for commercial laying hens without impairing the productive performance of these birds. This is because the optimum equilibrium of "less limiting" AA could reduce the use of AA as an energy source and increase their use in protein synthesis.

\section{Conclusion}

Individual supplementation with isoleucine, threonine or tryptophan makes it possible to reduce crude protein in the diet to $13 \%$ without compromising performance, egg quality or serum parameters of laying hens. Isoleucine can be the third limiting amino acid for laying hens fed under these dietary conditions according to serum parameters.

\section{Acknowledgments}

We would like to thank the National Council of Technological and Scientific Development (CNPq) for the economical support for this research and the Coordination for the Improvement of Higher Education Personnel (CAPES) - Brazil for the scholarship. 


\section{References}

AFTAB, U.; ASHRAF, M.; JIANG, Z. Low protein diets for broilers. World Poultry Science Journal, London, v.62, n. 4, p. 688-701, 2006.

CANH, T. T.; AARNINKA, A. J. A.; SCHUTTED, J. B.; SUTTON, A.; LANGHOUT, D. J.; VERSTEGEN, M. W. A. Dietary protein affects nitrogen excretion and ammonia emission from slurry of growing-finishing pigs. Livestock Production Science, Amsterdam, v. 56, n. 3, p. 181-191, 1998.

CORZO, A. Valine and isoleucine: their importance in broiler feed formulation. Aminonews, Essen, v. 9, n. 3, p. 15-21, 2007.

D'MELLO, J. P. F.; LEWIS, D. Amino acid interactions in chick nutrition. 2. Interrelationships between leucine, isoleucine, and valine. British Poultry Science, Edinburgh, v. 11, n. 3, p. 313-323, 1970.

FERNANDEZ, S. R.; AOYAGI, S.; HAN, Y.; PARSONS, C. M.; BAKER, D. H. Limiting order of amino acids in corn and soybean meal for growth of the chick. Poultry Science, Champaign, v. 73, n. 12, p. 1887-1896, 1994.

HARMS, R. H.; IVEY, F. J. Performance of commercial laying hens fed various supplemental amino acids in a cornsoybean meal diet. Journal Applied Poultry Research, Champaing, v. 2, n. 3, p. 273-282, 1993.

HARRIS, R. A.; KOBAYASHI, R.; MURAKAMI, T.; SHIMOMURA, Y. Regulation of branched-chain $\alpha$-keto acid dehydrogenase kinase expression in rat liver. Journal of Nutrition, Philadelphia, v. 131, n. 3, p. 841-845, 2001.

HAUGH, R. R. The Haugh Unit for measuring egg quality. United States Egg and Poultry Magazine, Chicago, v. 4, n. 43, p. 552, 1937.

HY-LINE INTERNATIONAL. Hy-line variety W-36 commercial management guide. West Des Moines: HyLine International, 2009-2011. 22 p.

ISHIHARD, A.; KURAHASI, K.; UEHARA, H. Enzymatic determination of ammonia in blood plasma. Clinica Chimica Acta, Amsterdam, v. 41, n. 1, p. 255261, 1972.

KESHAVARZ, K.; JACKSON, M. E. Performance of growing pullets and laying hens fed with low-protein amino acid-supplemented diets. Poultry Science, Champaign, v. 71, n. 5, p. 905-918, 1992.

KIDD, M. T.; BURNHAM, D. J.; KERR, B. J. Dietary isoleucine responses in male broiler chickens. British Poultry Science, Edinburgh, v. 45, n. 1, p. 67-75, 2004.
LOCATELLI, M. L. A review of the threonine, tryptophan, isoleucine and valine requirements of commercial laying hens. Aminonews, Hanau, v. 6, n. 1, p. 13-20, 2005.

MELLO, H. H. C.; GOMES, P. C.; ROCHA, T. C.; DONZELE, J. L.; ALMEIDA, R. L.; TRONI, A. R.; CARVALHO, B. R.; VIANA, G. S. Determination of digestible isoleucine:lysine ratio in diets for laying hens aged 42-58 weeks. Revista Brasileira de Zootecnia, Viçosa, MG, v. 41, n. 5, p. 1313-1317, 2012.

MORRIS, T. R.; GOUS, R. M. Partitioning of the response to protein between egg number and egg weight. British Poultry Science, Edinburgh, v. 29, n. 1, p. 93-99, 1988.

NAMROUD, N. F.; SHIVAZAD, M.; ZAGHARI, M. Effects of fortifying low crude protein diet with crystalline amino acids on performance, blood ammonia level, and excreta characteristics of broiler chicks. Poultry Science, Champaign, v.87, n. 11, p. 2250-2258, 2008.

OSPINA-ROJAS, I. C.; MURAKAMI, A. E.; EYNG, C.; NUNES, R. V.; DUARTE, C. R.; VARGAS, M. D. Commercially available amino acid supplementation of low-protein diets for broiler chickens with different ratios of digestible glycine+serine:lysine. Poultry Science, Champaign, v. 91, n. 12, p. 3148-3155, 2012.

PEGANOVA, S.; EDER, K. Studies on requirement and excess of isoleucine in laying hens. Poultry Science, Champaign, v. 81, n. 11, p. 1714-1721, 2002.

Interactions of various supplies of isoleucine valine, leucine and tryptophan on the performance of laying hens. Poultry Science, Champaign, v. 82, n. 1, p. 100-105, 2003.

PENZ, A. M.; JENSEN, L. S. Influence of protein concentration, amino acid supplementation and daily time of access to high or low-protein diets on egg weight and components in laying hens. Poultry Science, Champaign, v. 70, n. 12, p. 2460-2466, 1991.

RECH, O. A.; PINHEIRO, J. W.; FONSECA, N. A. N.; SILVA, C. A.; OBA, A. Efeito da linhagem, espaço na gaiola e nível de triptofano dietético no desempenho de poedeiras comerciais. Semina Ciências Agrárias, Londrina, v. 31, n. 4, p. 1051-1058, 2010.

ROSTAGNO, H. S.; ALBINO, L. F. T.; DONZELE, J. L.; GOMES, P. C.; OLIVEIRA, R. F.; LOPES, D. C.; FERREIRA, A. S.; BARRETO, S. L. T.; EUCLIDES, R. F. Tabelas brasileiras para aves e suínos. Composição de alimentos e exigências nutricionais. Viçosa, MG: UFV, 2011. $252 \mathrm{p}$.

RUSSELL, G. B.; HARMS, R. H. Tryptophan requirement of the commercial hen. Poultry Science, Champaign, v. 78, n. 9, p. 1283-1285, 1999. 
STATISTICAL ANALYSIS SYSTEM INSTITUTE SAS. SAS Institute. SAS Proprietary Software, Release 9. 2. SAS Inst. Inc., Cary, NC. 2009.

SHIVAZAD, M.; HARMS, R. H.; RUSSELL, G. B.; FARIA, D. E.; ANTAR, R. S. Re-evaluation of the isoleucine requirement of the commercial laying. Poultry Science, Champaign, v. 81, n. 12, p. 1869-1872, 2002.
SOHAIL, S. S.; BRYANT, M. M.; ROLAND, D. A. Influence of supplemental lysine, isoleucine, threonine, tryptophan and total sulfur amino acids on egg weight of Hy-Line W-36 hens. Poultry Science, Champaign, v. 81, n. 7, p. 1038-1044, 2002.

WALDROUP, P. W.; KERSEY, J. H.; FRITTS, C. A. Influence of branched-chain amino acid balance in broiler diets. International Journal of Poultry Science, Faisalabad, v. 1, n. 5, p. 136-144, 2002. 
